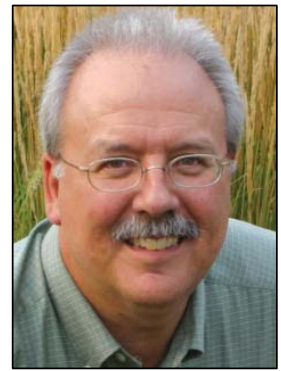

\author{
METRICS FROM THE FIELD \\ Blending insights from research with insights from practice \\ Ken Meter
}

\title{
Breaking our chains
}

Published online 10 July 2011

Citation: Meter, K. (2011). Breaking our chains. Journal of Agriculture, Food Systems, and Community Development, 1(4), 23-25. http://dx.doi.org/10.5304/jafscd.2011.014.008

Copyright (C 2011 by New Leaf Associates, Inc.

W ith all due respect to my professional colleagues who expertly address supply chains on other pages of this issue, I want to step back to consider whether we might break the "chains" that inhibit our conversation about food.

I am concerned that our laudable goals of providing accurate measurements and establishing new business practices may interfere with our chance to take advantage of this historic opportunity to get the food systems we deserve. The way we frame the discussion may only lead us to replicate the problems we seek to address. This is not an issue of political correctness; it is a matter of obtaining the proper results.

Community groups who are free build networks, not chains, and this often means that residents find "supply chain" or "value chain" constructs limiting. Ken Meter suggests we frame food systems work in terms of "value networks." He asks, "should we model our food systems after our economic models, or build economic models that help us construct the food systems we deserve?"
Privately, I have discussed this with respected colleagues. I've pointed out that the "chain" metaphor is problematic for many of the communities where I work. First of all, it is a linear concept, and linear constructs tend to be less flexible, and less inclusive, than those that describe circles. Second, some people associate chains with captivity, rather than freedom and democracy; chains are usually

Ken Meter is president of Crossroads Resource Center in Minneapolis, Minnesota. He has performed 63 local food-system assessments in 27 states and one Canadian province; this information has promoted effective action in partner communities. He served as coordinator of the review process for USDA Community Food Project grants, and has taught economics at the Harvard Kennedy School and the University of Minnesota. He is co-convener of the Community Economic Development working group of the Community Food Security Coalition. A member of the American Evaluation Association's Systems Technical Interest Group, Meter also serves as an Associate of the Human Systems Dynamics Institute. He serves as a contributing advisor to JAFSCD. 
yanked by the powerful at the expense of those less powerful. Third, free communities don't build chains; they build networks, and draw inclusive circles.

Recognizing that the fundamental purpose we have in refashioning food systems is to build strong, democratic communities that know how to feed themselves - no community (or nation) can be self-determined if it imports most of the food it eats - the concept of "supply chain" is problematic. Some have refined this to "value chain," or even "values chain." I prefer a fourth construct: "value network." Residents are already building networks; people are pleased to find a model that encompasses the progress they have already made.

Privately, my colleagues agree with me, but then in a low voice, often add, "Still, we have to use the term 'supply chain,' because that is the industry standard." Perhaps it is time to put this industry standard into the compost pile of history that includes terms such as "The Negro," "The Spanish-American War in the Philippines," and "trickle-down economics." Each was once standard; each has been superseded.

Let's take a look at a typical "supply chain": denied. This can be a useful framework for conceiving of greater efficiencies.

The chain model also helps us look more deeply at the economics. Although we like to believe that supply and demand always "balance," this diagram shows rather eloquently that supply and demand are not even in conversation with each other. Rather, growers respond to market signals from buyers and brokers, while consumers respond to advertising from retailers and institutions. Without direct negotiations between farmers and eaters, there can be no balance.

Moreover, if you look at the USDA "food bill" data $^{1}$ (ERS, annual series) you will find that, despite the one-way arrows pointing to the right on this diagram, the value produced along this chain is sucked into the middle, at the expense of both producers and consumers. Food processors and buyers earned a cumulative revenue of US $\$ 13$ trillion during the years 1950-2006 more than three times the revenue farmers earned by selling commodities. Although farm sales doubled during that period and farm productivity more than doubled, farmers earned $19 \%$ of the ultimate retail value of food (US $\$ 900$ billion) in 2006, compared with $41 \%$ in 1950 ,

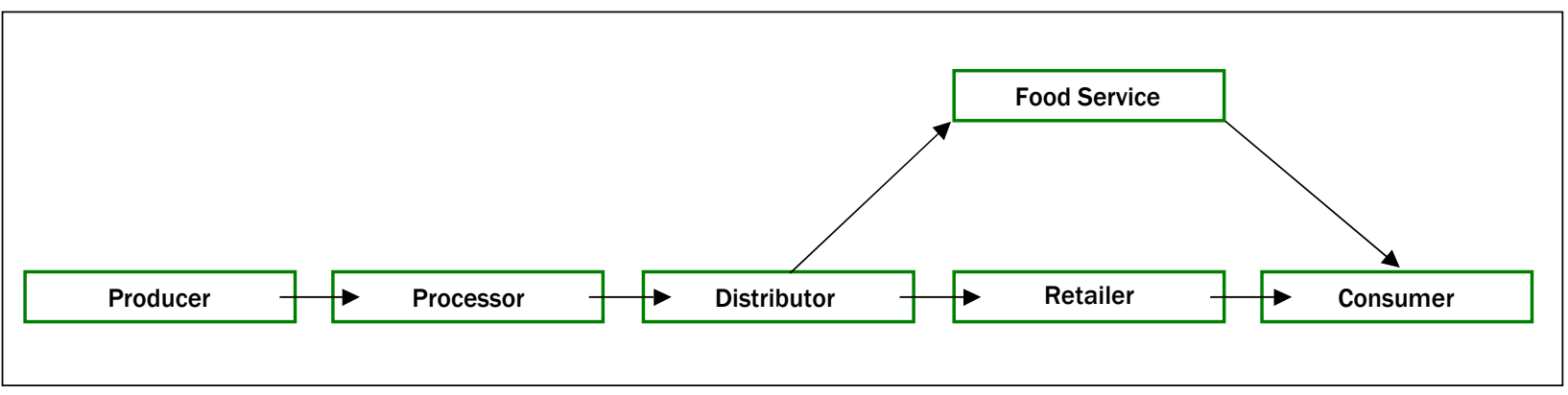

I know this chain is a useful construct; I use this in most every speech I make. I have drawn more complicated diagrams, using this as a backbone, in my own work (Meter, 2009, p. 48). Its value as a linear paradigm, it seems to me, is considerable: an economist can parse out different steps in the food supply process and carefully calculate the value added at each step of the process. Its heuristic value as a simplification cannot be when retail food sales totaled US $\$ 44$ billion.

So while the chain diagram is useful, it also omits several critical aspects of the food systems we actually live within. While no model is complete,

1 The USDA Economic Research Service has replaced the "Marketing Bill" series with the "Food Dollar" series; see http://www.ers.usda.gov/Data/FoodDollar/whyreplace.htm 
of course, these seem to be important oversights. For one thing, the chain diagram above would suggest that having clean air or water, and fertile soil, has nothing to do with delivering the foods we eat. In particular, the idea that "waste" from the production, processing, or consumption process might be recycled into new fertility for the soil is overlooked. Were these aspects encompassed in the diagram, we would be drawing circles.

Secondarily, the chain construct may make it harder to address other concerns.

This diagram does not suggest that large food distributors might make loyalty payments, or kickbacks, to their customers, yet this is standard industry practice. This model tracks cash flows, but not assetbuilding or ownership. It would be easy, examining this design, to overlook the fact that many primary commodity producers (i.e., farmers) are chronically selling their products for less than the cost of production. It is difficult to point out, using this model, the fact that many of the spendy gourmet foods we can now enjoy at urban markets are produced by migrant labor working at minimum wage. Externalized costs of pollution are, well, externalized. Failing to include many of these costs may indeed show up as "efficiencies" on the supply chain.

The very abstract nature of the chain model also may interfere. It is easy to forget, while pondering this diagram, that "going to scale" is a strategy, not a purpose. If tax policies favor business expansion, measurements of "value added" at each step are altered, but may not be visible on a diagram that does not include public entities. Moreover, narrow definitions of "efficiency" at the firm level often create inefficiencies for the community, but this is difficult to show. Also missing is the role of nonprofits, which may convene diverse players in the system, or frame lasting visions, adding value to the entire system. Since food system practitioners report that building lasting relationships of trust is essential to creating both value and competitive advantage (Meter, 2009), it is striking that these do not appear on the chain. systems we actually live within....

would suggest that having

clean air or water, and

fertile soil, has nothing to

do with delivering the

foods we eat.
As a substitute to the chain, I find myself diagramming the food systems work that is already underway in a given community. In each case, the diagram reflects a network, one that is unique to the assets of that specific time and place. Calculating the economics of these networks is complex, but a number of good systems thinkers are devising techniques to do so. In any case, at the community level, I ask for an early conversation about how to measure what matters the most in achieving the community's vision. If we find ourselves describing a linear connection, someone often suggests a way to show how that is part of a circle.

Ultimately, it becomes a matter of hubris. Do we model our food systems after our economic models, or do we build economic models that help us construct the food systems we deserve?

\section{References}

Meter, K. (2009). Mapping the Minnesota food industry. Minneapolis, MN: Crossroads Resource Center. Available at http://www.crcworks.org/mnfood.pdf

U.S. Department of Agriculture Economic Research Service. Food dollar series. (Annual series). Available at http://www.ers.usda.gov/Data/FoodDollar/ index.htm 
Journal of Agriculture, Food Systems, and Community Development ISSN: 2152-0801 online www.AgDevJournal.com 